\title{
Energy Governance in Hungary
}

\author{
John Szabo, Csaba Weiner, and András Deák
}

\section{Contents}

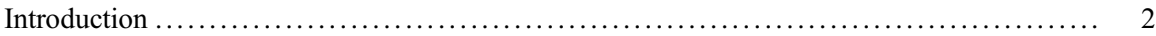

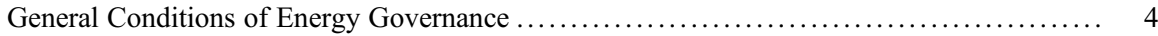

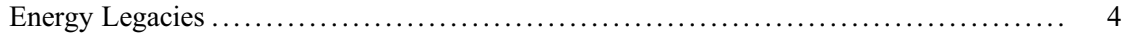

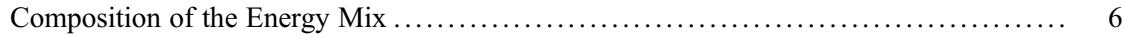

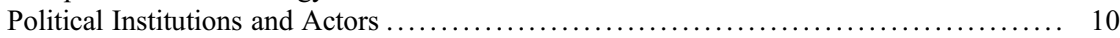

Discourse on Energy Issues ............................................ 13

Coordination of the Instruments and Issues of Energy Transitions Within a Multilevel

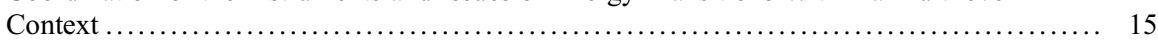

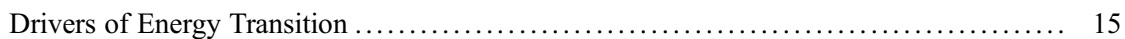

Strategies and Instruments of Energy Transition .............................. 17

Coordination Mechanisms and Multilevel Governance ............................ 21

Outcomes, Challenges, and Prospects of Energy Governance ........................ 24

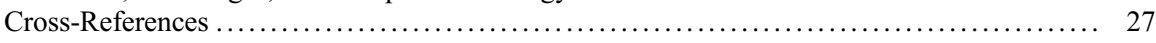

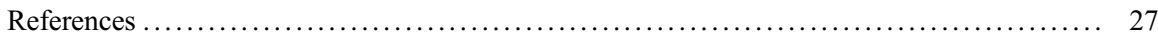

\footnotetext{
J. Szabo $(\triangle)$

Department of Environmental Sciences and Policy, Central European University, Budapest, Hungary

Institute of World Economics, Centre for Economic and Regional Studies, Budapest, Hungary e-mail: szabo_john@phd.ceu.edu

C. Weiner

Institute of World Economics, Centre for Economic and Regional Studies, Budapest, Hungary e-mail: weiner.csaba@krtk.mta.hu
}
A. Deák
Institute of World Economics, Centre for Economic and Regional Studies, Budapest, Hungary
Institute of Strategic and Security Studies, National University of Public Service, Budapest, Hungary
e-mail: deak.andras@krtk.mta.hu 


\section{Abstract}

Hungarian energy governance conveys a unique disposition, filled with contradictions, lacking clarity, but reflecting centralized control at the highest echelons of politics. Like many of its Central and Eastern European (CEE) neighbors, it is still entrenched in preexisting producer-consumer relations that shape its amicable relations with Russia, while its accession to the European Union has led it to take on disruptive climate and energy policy targets. The country's energy transition has been unfolding slowly, as the government maintains a moderate pace of action. The diffusion of renewables continues to unfold in the shadow of other historical legacies, most prominently Russia-sourced nuclear power technology, natural gas, and oil. Power and control over energy corporations is concentrated in the hands of those closely aligned with the government, and multilevel governance is subordinated to anticipate or execute the objectives dictated by political leaders. Challenges mount in the Hungarian sector as we move towards the 2030 and 2050 EU decarbonization targets, which will pressure the government to implement much more disruptive measures, severing and rewriting historical energy based ties.

\section{Keywords}

Energy governance $\cdot$ Hungary $\cdot$ Lock-in $\cdot$ Government control $\cdot$ Centralization Energy transition

\section{Introduction}

Hungary's energy system reflects the imprint of an energy system conveying typical Central and Eastern European (CEE) patterns combined with Prime Minister Viktor Orbán's general approach to political economics. The energy scene is shaped by powerful path dependencies: reliance on Russian hydrocarbons and nuclear technology as well as relatively low GDP per capita leading energy bills to constitute a higher share in total household expenditure. Motorization has been in full swing and GDP growth is higher than the EU average, both driving a rise in energy and especially electricity consumption. Reducing greenhouse gas (GHG) emissions has not been a prominent issue until very recently, due to deindustrialization and a related fall in emissions after the regime change in 1989. EU targets concerning renewable energy and emissions from sectors not included in the EU Emissions Trading System (EU ETS) pose a growing challenge for the country, leading Hungary to engage in tug-of-war over how the energy transition's costs should be split between CEE and other Western EU states. Amidst these, PM Orbán's approach to energy governance has continued to primarily focus on exploiting utility price controls for political gain, the nationalization of energy assets, and centralizing control over the sector. Overall, Hungary shows few signs of being the exception among the EU's energy governance models. It shares a multitude of similarities with CEE countries, while perhaps being a bit louder, more intractable, and intrusive than its regional counterparts. 
The current form of Hungary's energy system has co-evolved with the political economics of the Orbán regime. Fidesz reshaped the fundamentals of the Hungarian constitutional order and cemented its extensive rule over the country after it gained a supermajority in the 2010 elections. The set of these all-encompassing changes ushered in what some have referred to as "Orbánism," despite its lack of a coherent ideology and multiplicity of interpretations (Müller 2014). PM Orbán often positions himself in defiance of the declining Western liberal order, lamenting the withering away of traditional values and offering to restore those. Orbán (2014) claimed that he aimed to establish an illiberal democracy, incorporating the convergence of nationalism and capitalism. His governance has also been assessed as a "hybrid regime" (Filippov 2018), implying a competitive market coupled with authoritarian rule, or a "postcommunist Mafia state" (Magyar 2016), a crony capitalist entity. Scheiring (2018) describes this Hungarian regime as an authoritarian accumulative state in a dependent market economy environment, which simultaneously incentivizes the formation of a strong national capitalist class and multinational investment. The "developmental state" arguments within the world-systems theory highlight the later features and present Hungary as a country serving international capital and striving to upgrade its standing in the global division of labor (Wilkin 2016).

Characterizing Hungary's political economics as well as its embeddedness in European and global relations of production are essential to understand the country's approach to energy governance. The aforementioned interpretations and approaches of the Orbán regime treat local energy trends and developments differently. The hybrid regime approach proposes that energy is a linchpin connecting Hungary to other illiberal states, most notably Russia (Filippov 2018). The crony capitalist narrative suggests that nationalization within the sector serves as a mode of politically motivated sectoral rent redistribution, while the related neo-utilitarian interpretation describes the strong focus on reducing utility prices as an indelible mark of excessive politicization of the matter (Magyar 2016). The accumulative state approach argues that the sector was a target of the revolting national bourgeoisie (Scheiring 2018). Dependency and world-systems theories focus on Hungary's reliance on importing hydrocarbons to ensure its competitive role in global supply chains, leading it to shape intricate linkages with resource exporting countries, such as Russia. This approach also suggests that Hungarian laggardness in climate policies can be understood as an effort to maintain inexpensive inputs for multinational companies. While all these features are true for Orbán's Hungary, they also indicate the complexity of local energy governance and its intractability within a single existing theory.

The following chapter attempts to provide an overview of the focal mechanisms shaping energy governance in Hungary. In section "Energy Legacies", it explores the historical legacies shaping the energy system in place today, by introducing the country's reliance on Russian hydrocarbon imports and nuclear technology. It then turns to the composition of the country's energy mix (section "Composition of the Energy Mix"), providing an overview of the status quo, which indicates the potential extent of an energy transition. Subsequently, it discusses the main actors in Hungary's energy scene and prevalent discursive themes (section "Political 
Institutions and Actors"). In section "Drivers of Energy Tranition", the chapter explores the drivers of an energy transition, where energy security will be a crucial factor that the authors flesh out in more detail. After this, the chapter turns to the specific strategies the government and the energy sector have adopted to meet energy transition goals (section "Strategies and Instruments of Energy Transition"), pertaining to both energy security and decarbonization, before discussing the characteristics of Hungary's multilevel governance in the sector (section "Coordination Mechanisms and Multilevel Governance"). Finally, in section "Outcomes, Challenges, and Prospects of Energy Governance" we draw conclusions and discuss what our findings imply for the energy sector's governance in light of the need to undertake an energy transition.

\section{General Conditions of Energy Governance}

\section{Energy Legacies}

Hungary was the third most energy dependent country of the 11 Eastern EU member states in 2018 with an import ratio of 58.1\% (Eurostat 2020a). By reclassifying nuclear energy from domestic to imported fuel, warranted by Hungary's importation of the technology and source fuel (BP 2019a), the country's dependency rate would be over $73 \%$. It would approach Lithuania's $77.2 \%$, the most dependent former Eastern bloc state. Resource scarcity and declining production levels became wellestablished trends after the early 1970s, resulting in a steep increase of Soviet imports of electricity as well as fossil and nuclear fuels. Hungary established an energy resource trade regime and constructed the physical infrastructure with the Soviet Union between the 1960s and the1980s that resembled general Comecon patterns (Szabo and Deak 2020). Basic patterns of energy relations still preserve the imprints of the Socialist era. The first connection between the Soviet and Hungarian oil networks was the Friendship (Druzhba) pipeline in 1962, still functioning as the main route for imports. First gas deliveries from the Soviet Union arrived in 1975 through the Brotherhood (Bratstvo) pipeline. Between 1982 and 1987 four Soviet VVER-440 nuclear blocs were constructed in Paks, still providing the bigger half of domestic electricity supply. The rest of the electricity generation fleet consists of different, primarily Soviet-era natural gas power plants and the lignite-based Mátra Power Plant at Visonta, built between 1969 and 1972.

Energy dependency remained a recurring concern of Hungarian energy policy, especially after the 1989 dissolution of the Soviet bloc, but policy-makers made limited effort to change the situation. Affordability considerations - cheap and convenient energy supplies for households in particular - constituted the top political priority following the country's regime change. In the early 1990s, this manifested in excessive and politically supported gasification programs, while after the turn of the millennium discourses on low utility prices became a distinguished field of domestic political competition (Szabo and Fabok 2020). Affordability issues are considered a legacy from the communist era. After the 1956 failed revolution, the initially 
unpopular Kádár regime achieved social consolidation by making welfare concessions to the masses. Trade-offs between political loyalty and economic benefits, "Gulash communism" became a systematic feature of Hungary for the next 30 years, creating an increasingly paternalistic-populistic embeddedness for upcoming governments (Benczes 2016). The major expectation from regime change in the 1990s was not necessarily related to political freedoms, but to higher living standards, preserving broad social guarantees (a sort of "Gulash capitalism"). Consequently, increased estrangement from emerging market institutions and democratic competition as well as nostalgia toward the Kádár regime developed amongst the populace (Pap 2017).

Attitude towards Russia also remained relatively friendly following the system change. Until 2010, Hungary had a quasi-bipolar political system, dominated by the Russia-pragmatist leftist communist successor party and Russia-skeptical conservative forces. Since 2010, Viktor Orbán has transformed from a fierce Moscowopponent to a proponent, driving the positive views of Russia at both party and societal level. Even the far-right nationalist party, Jobbik, has become pro-Russia and only tiny green and liberal formations in the parliament maintain Russia-skeptic positions. According to opinion polls conducted after the Russian-Ukraine conflict in 2016, 58\% of the respondents supported closer economic ties with Russia, $28 \%$ opposed those, while one-third of the population could have even imagined political rapprochement (35\% for and 40\% against) (Szvák 2016). Consequently, Hungary's perception and relations with Russia is a relatively weak driver to change the existing energy status quo.

Ownership relations comprised another focal point of Hungarian energy policies. Due to the government's high indebtedness and austerity measures following the regime change, it sold a significant part of the natural gas and electricity industry to foreign multinationals in 1995 . This early privatization and the accompanied establishment of an independent regulator to secure the $8 \%$ profit rate for new incomers became a major cleavage between the political left and right (Mocsáry 2001; Báger and Kovács 2004). Early privatization led to a colorful ownership pattern for the next 15 years. The nuclear energy generation and the electricity transmission system operator (TSO) remained in the hands of a state-owned enterprise (SOE), MVM (Hungarian Electricity Works). The oil industry and various parts of the gas sector (most notably the gas TSO) came to be owned by domestic private actor, MOL. Meanwhile, all other assets including electricity and gas distribution and a number of power plants were sold to foreign, predominantly European, multinational corporations. After 2010, PM Viktor Orbán enlisted the energy sector as a strategically important branch of the economy, where Hungarian ownership shall prevail. By the end of his second term in office, foreign companies were mostly squeezed out by regulatory means and/or purchased by local and state entities. Investments into the electricity sector, for example, were major victims of the Orbán governments' reforms (Eurostat 2020a, b). Investment intensity per consumption practically halved after 2011, a decline that can be only partly explained by the financial crisis and higher electricity imports. Initially this was due to voracious nationalization efforts, but low sectoral profitability sustains due to utility rate setting. The outcome 
of these changes is that the Hungarian energy landscape became subject to strong political control through formal and informal means, with little autonomy for the regulator and increased statist attitudes in management and planning.

The government of Hungary welcomed EU policies and common governance in a restrained manner and applied these initiatives selectively. Hungary was an early mover to enhance natural gas interconnections and implement supply security policies, leading EU efforts and taking advantage of supranational support following the 2009 Russian-Ukrainian gas disputes. The European Commission's bids to further market coupling and unbundling had a more selective reception and required longer adaptation. Common climate policy objectives, especially regarding renewables and non-ETS administrative measures, comprise the biggest emerging point of conflict between the government of Hungary and its Western counterparts. The former has been footdragging, accepting new targets only conditionally and under external pressure. 2017 GHG emissions may have been $31.9 \%$ lower, at 63.8 million tons of $\mathrm{CO}_{2}$ equivalent $\left(\mathrm{MtCO}_{2} \mathrm{eq}\right.$ ), than 1990 figures of $93.8 \mathrm{MtCO}_{2} \mathrm{eq}$, but most of the decrease is due to the deindustrialization during transition years following the collapse of the communist regime. The trajectory of GHG emission declines have, however, reversed since 2015, steadily rising in subsequent years (ITM 2020b). Meanwhile, few domestic drivers for a more ambitious climate stance have been visible, and the Orbán government views the matter through a lens of short-term cost-benefit calculations. Climate policy and energy transition commitments largely rely on external, mainly Western and the European Commission's pressure as well as domestic industrial policy.

Hungarian energy policy has maintained its Russia-focus by renewing natural gas and nuclear contractual relations, the preeminence of sovereignty and affordability of energy policy, restored formal and informal statism, while firmly maintaining its position among climate laggards. Policy attitudes seem to be fairly stable under the Orbán government, but institutions lack any solid fundamentals and have been subservient to political objectives. Until 2010, policy controls over the industry were relatively weak, usually set under the Ministry of Economy with rare interferences from the Prime Minister's side in issues such as Russia or hostile acquisition attempts from foreign companies. After 2010, energy became a sector closely and actively managed at the highest political level. PM Viktor Orbán takes an active decision-making role in a set of major issues, while policy supervision became increasingly fragmented between various entities whose roles were regularly reshuffled by the PM.

\section{Composition of the Energy Mix}

Hungary features a heavily import-dependent hydrocarbon-based energy system, predicated on its legacies and shaping its approach to the sector's governance. The country used hydrocarbons to meet $69.2 \%$ of its gross inland consumption in 2018 , dominated by natural gas (31.0\%) and closely followed by oil and petroleum products $(30.3 \%)$. Nuclear energy held a $15.0 \%$ share, exceeding both renewables and biofuels $(10.5 \%)$ as well as solid fossil fuels (7.9\%) in gross demand (Table 1) (MEKH 2020f). In 2017, the country's GHG emissions amounted to $63.8 \mathrm{MtCO}_{2}$ eq not including land use, land use 


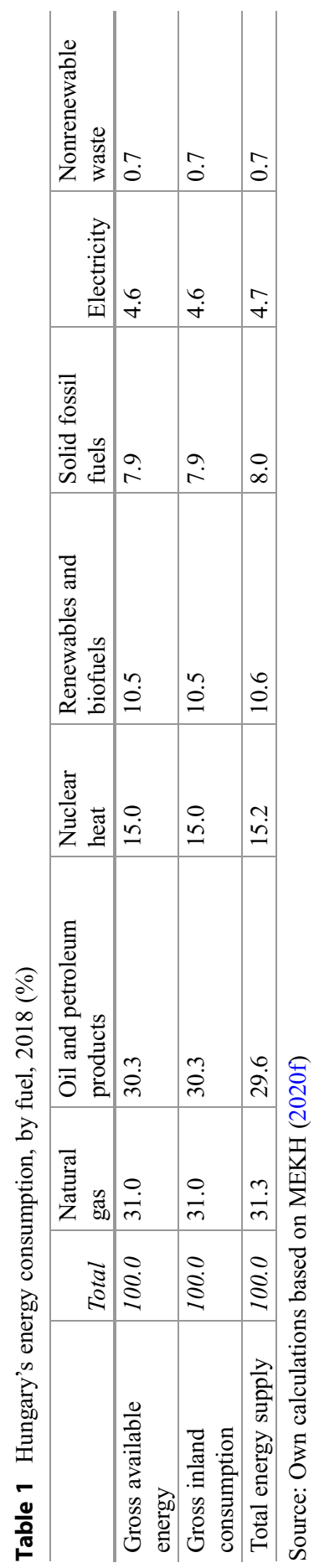


change, and forestry (LULUCF), with the energy sector accounting for $72 \%$ of emissions (ITM 2020c). Hungary imports the bulk of its primary energy supply, apart from domestically produced lignite. Regarding natural gas, the production-to-consumption ratio has fallen below $20 \%$. Hungarian gas production declined rapidly until 2015; since then, it has grown slightly (MEKH 2020c). There were significant hopes for unconventional gas, but this has proven to be an illusion. Approved in January 2020, Hungary's National Energy and Climate Plan (NECP) states that natural gas production may continue to grow through 2030 , to which unconventional gas will only make a very small contribution (ITM 2020c, 202-203). Oil production is growing much more rapidly (MEKH 2020d), but despite a large oil field discovery, recently announced, it will still be limited. According to the NECP, in 2030 oil production will be lower than the current level, but increases will be seen in the mid-2020s. Currently, oil imports account for around $90 \%$ of consumption (ITM 2020c, 31, 202).

Hungary's final energy consumption has been quite fluctuant since the fall of the communist regime with natural gas playing a key role in meeting demand. Between 2014 and 2017, total final energy consumption grew at a rate well above the EU average, in-part reflecting wastefulness, but this trend stopped in 2018, and residential consumption declined (the latter is mainly because of the mild winter weather, though) (Eurostat 2020a; MEHI 2019; MEKH 2020f). The residential sector has the largest share in final energy demand $(32.6 \%$ in 2018), followed by the transport $(26.9 \%)$ and the industrial sector (24.9\%) (MEKH 2020f). The residential sector primarily relies on gas (48.6\% in 2018), followed by renewables (23.6\%), electricity $(16.8 \%)$, derived heat $(8.0 \%)$, coal and coal products $(1.6 \%)$, as well as oil and petroleum products (1.3\%) (Table 2) (MEKH 2020e). Hungary's transportation sector, on the other hand, consumes petroleum products to meet rapidly growing demand. In 2018, 62.2\% of consumption was diesel (MEKH 2020f) leading Hungary's Russian crude-based oil refiner to optimize for diesel production.

The share of renewables in gross final energy consumption only reached $12.5 \%$ in 2018, most of which is in the heating sector (Fig. 1) (ITM 2018; MEKH 2020h). Solid biomass is the dominant renewable energy source, amounting to $77.3 \%$ of renewable consumption in 2018 (MEKH 2020g). This is almost exclusively constituted of firewood, with straw playing a measurable, but relatively minuscule role. The majority of this biomass is consumed by the household sector, also entailing that Hungary's ability to meet its EU renewable energy target heavily relies on household biomass consumption.

The relative role of nuclear, coal, natural gas as primary fuels, and that of electricity imports have been volatile in Hungary's electricity supply in past years, changing with market and policy conditions (Fig. 1). Electricity consumption increased until 2007 to $43.9 \mathrm{TWh}$, followed by a fall in 2009. The years 2010 2014 brought stagnation (42-43 TWh), but consumption has been growing since 2015 and climbing to over 46 TWh in 2018 (Eurostat 2020c). Hungary's domestic generation is heavily reliant on the Paks Nuclear Power Plant and the Mátra Power Plant. Gas comprised the largest share in 2007 and 2008, followed by nuclear, and coal was a distant third. Market shares were reshuffled by the mid-2010s, when nuclear's role increased to over $50 \%$, while coal overtook natural gas in relative 


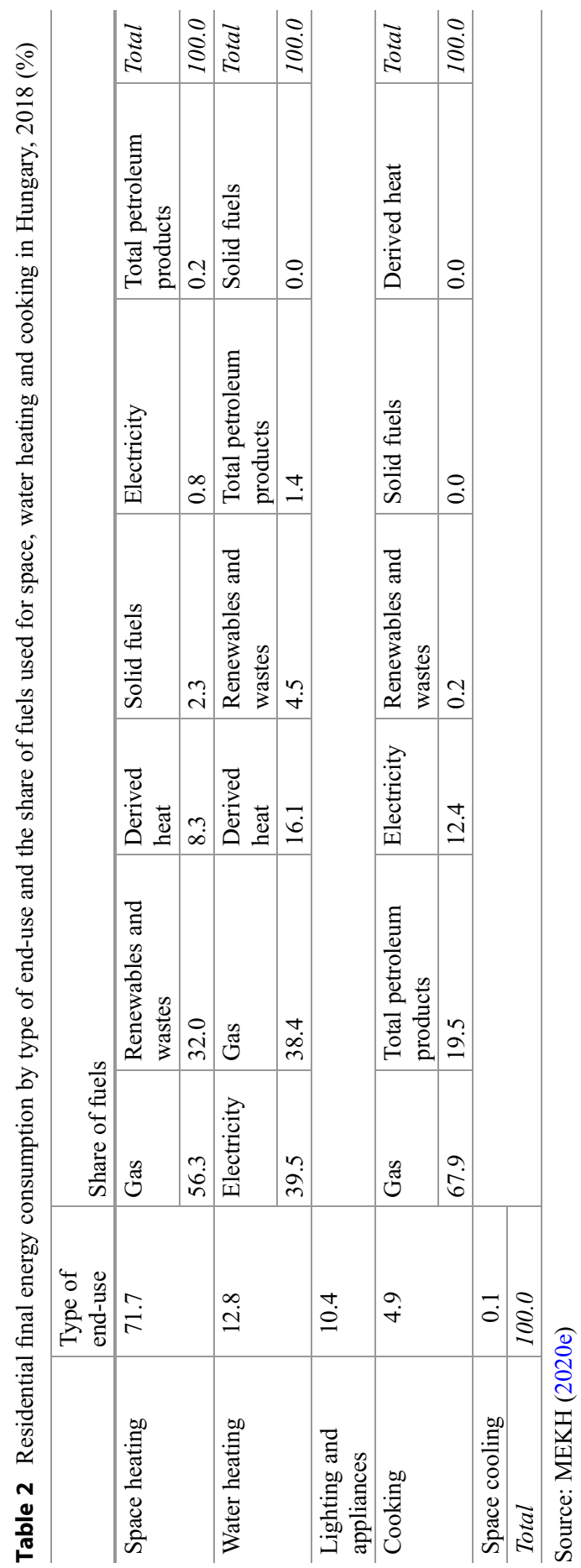




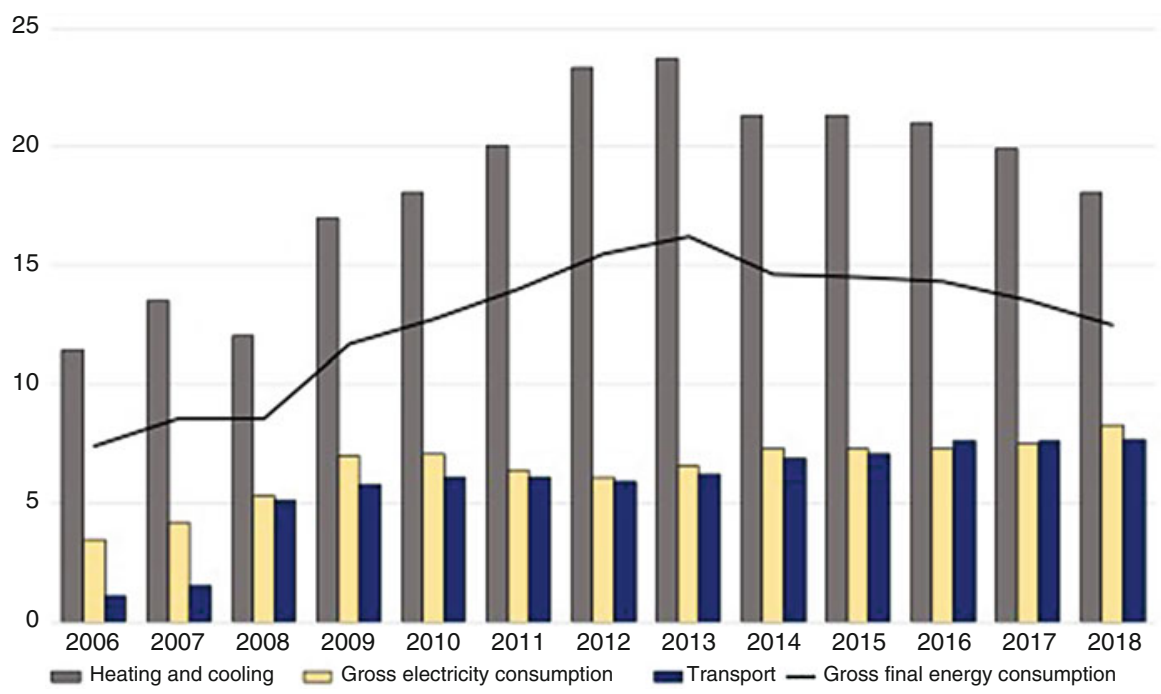

Fig. 1 Share of energy from renewable sources in Hungary, by sector, 2006-2018 (\%). (Source: MEKH 2020h)

importance. These developments were paired with a surge of electricity imports to more than 30\% of demand in 2014 and 2015, compared to around $9 \%$ in 2007 and 2008 (Eurostat 2018a, 2020c; MEKH 2020a). Shifts have been the result of (1) natural gas' competitive disadvantage, (2) low carbon prices, and (3) low electricity prices (Stern 2017; KWK-Index n.d.; Sandbag n.d.).

As climate consideration came to play a growing role, coal lost its relative competitiveness vis-a-vis natural gas, in part due to the rise of carbon prices since 2015 (BP 2019b; KWK-Index n.d.; Sandbag n.d.). Coal's role in Hungary's electricity generation dwindled and natural gas' increased. Nuclear's and electricity imports' roles have slightly decreased, while renewables' relative role has climbed, reaching 11.6\% in 2018 (Fig. 2). However, biomass continues to play the role of the largest source of renewable electricity generation, the sustainability of which is still disputed by various stakeholders (EASAC 2019). Hydro energy was the second most important source of renewable electricity until 2008, but wind energy took its place between 2009 and 2017 (Fig. 2). Due to the government's failure to grant new wind permits and the subsequent de facto ban on new wind projects, emerging solar PV overtook wind in 2018. Despite some changes, the nuclear-gas-coal-biomass electricity generation composition has continued to dominate the sector.

\section{Political Institutions and Actors}

Energy governance is highly fragmented in Hungary, with influence over policy and market developments divided between multiple ministries and private actors. In theory, the Ministry of Innovation and Technology is at the center of energy policy, but competences are split with other ministries, while PM Orbán and his office have 


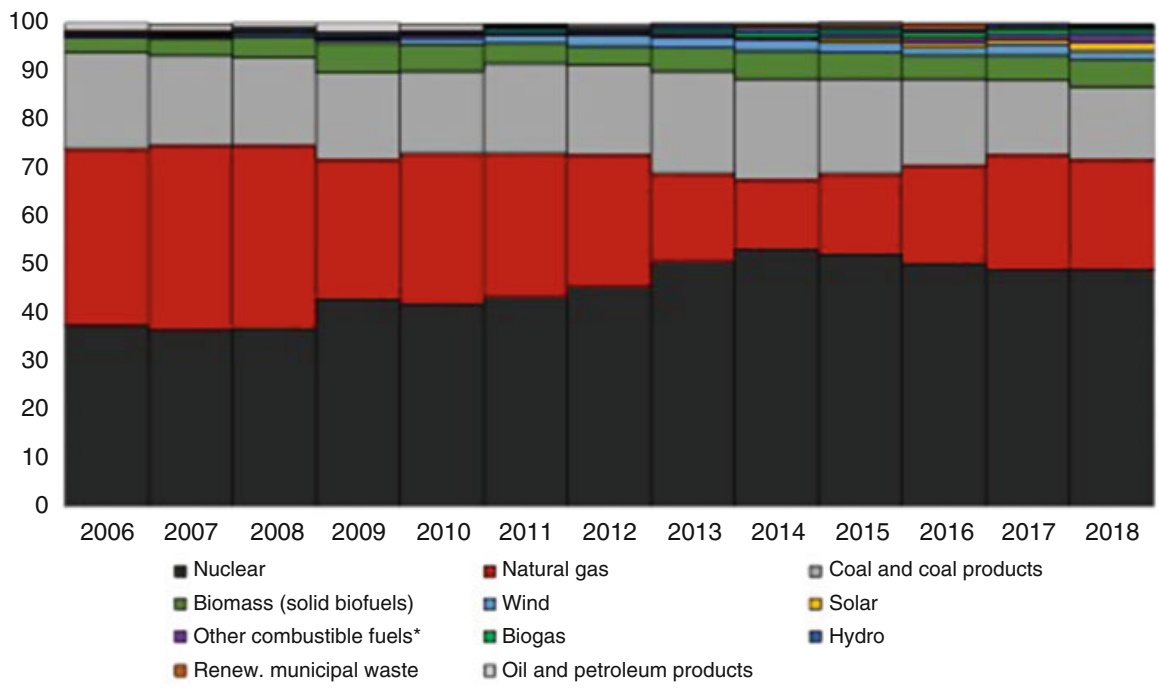

Fig. 2 Gross electricity production in Hungary, by fuel, 2006-2018 (\%) (Source: Own calculations based on Eurostat (2018a, b) for the years 2006-2013, and MEKH (2020a, b) for the years 2014 2018) $[*$ Other combustible fuels $=$ industrial waste + nonrenewable municipal waste + other sources]

the last say in prominent issues. The Ministry of Innovation and Technology has held the responsibility for planning activities and developing a strategy for energy and climate issues since 2018. However, according to the organization and operational rules of the ministry, the state secretary in charge is only responsible for climate policy related issues and "establishing the strategic conditions for energy business" (ITM 2019). The state secretary has been particularly active in fields of renewables, designing and managing related subsidies and auctions, as well as streaming investments into efficiency and environmental projects.

Natural gas issues and their links to foreign affairs are managed by the Ministry of Foreign Affairs and Trade. Since 2014, when the Orbán-confidant Péter Szijjártó was nominated to foreign minister, negotiations about gas pipelines, long-term supply contracts and import prices, regional and interconnectivity projects firmly belong to this unit of the government. While it is officially mandated to only coordinate energy and climate diplomacy (KKM 2019), it has a more active role in natural gas and some oil-related issues. The ministry's elevated status largely stems from strong personal ties between Minister Szijjártó and PM Orbán and their bid to closely control all gas-related issues.

In principle, the nuclear industry and the management of the new nuclear blocs' construction exclusively belong to the "Minister without Portfolio for maintaining the capacity of the Paks nuclear power plant." Despite the existence of such a portfolio, related issues are also regularly discussed at Putin-Orbán summits and the Prime Minister's Office has also been involved since the onset of the project - represented at ministerial level since 2018. The separation of the project can be justified by its complexity, its magnitude (EUR 12.5 billion, roughly 9\% of the 2019 Hungarian 
GDP), its sensitivity with respect to domestic policy and obvious delays in its completion. Besides low utility prices for households, the Paks II project constitutes the other fixed points of any governmental thinking on the future energy landscape.

While these players remain relatively visible, the Minister without Portfolio in charge of National Assets also takes on an important role in the domestic energy scene. Ministries often controlled SOEs in their respective fields in the past; but ownership control has been separated from policy supervision under Orbán's governments and state ownership has dramatically increased. The controlling ministry shall allocate investment funds for respective development projects within SOEs, can veto any major decision, as well as approve all nominations in the management and board. Theoretically, this should not be a problem, as long as the government can preserve its unity, but the separation between corporate and political control certainly represent a potential point of conflict. This affects the energy scene primarily through its say in the governance of Hungarian Electrical Works Plc. (MVM), the country's utility behemoth.

A further key actor is the Hungarian Energy and Public Utility Regulatory Authority (MEKH), established by the National Assembly of Hungary in its current form in 2013. In doing so, its scope of competences was broadened with the waste, water, and district heating sectors, but its price setting and controlling authority visa-vis the government were weakened. MEKH pursues conventional regulatory activities such as licensing, supervision, and statistical data collection. Nevertheless, its most important duty is tariff-setting and keeping the administratively managed pricing system in the household sector under the government's firm control.

Despite high levels of foreign ownership in the past, national private and state companies have always enjoyed a good deal of legal and financial support from the government. MOL was defended from hostile takeover attempts by Russian (2001, 2011) and Austrian (2009) companies. The close links between the government and MOL led the latter to cooperate in strategy-design and implementation. These included the creation of the strategic gas storage after 2009 and the development of the country's energy interconnections. Alongside MOL, a number of private entities play focal roles in the domestic energy scene. German E.ON's purchase of MOL's natural gas wholesale and storage firms drove foreign ownership in the sector to a peak. Due to their multinational corporate strategies, foreign companies became less involved in Hungarian policymaking and tensions at the regulatory level were always relatively high between private and public actors. The issue's relevance has declined since the mid-2010s due to extensive (re-)nationalization.

At the heart of this multiactor energy system is PM Viktor Orbán and the parliamentary majority his party has held since 2010. This horizontally fragmented and vertically integrated decision-making system relies on his political interests, circumstances, and room for maneuver regarding energy policy. He uses selected issues from the energy field for political purposes, including control over utility prices, as well as Russia-policy and nuclear developments. Simultaneously, growing climate consciousness offers increasing gains for various opposition parties. Fidesz followed a climate-neutral, mildly climate skeptical conservative line, putting the government into the defensive, against a mix of green and liberal parties. Changes in this approach are only beginning to surface. 
A final cluster of actors active in Hungary's energy sector is composed of those which are neither government entities nor private corporations involved in the energy supply chain. This includes independent nongovernmental organizations, such as Energiaklub, National Society of Conservationists - Friends of the Earth Hungary, or Greenpeace Hungary, which have had a limited capacity to shape policy and have frequently faced hostility from Orbán governments.

\section{Discourse on Energy Issues}

The themes of energy prices, energy security, ownership of energy assets, and nuclear power have been at the center of energy discourses in Hungary, with climate changes' importance only recently rising. The most pervasive energy discourse in Hungary pertains to price, which has been a key political issue for decades (Szabo and Fabok 2020). The Hungarian government has traditionally taken a paternalist role in society dating back to the communist era. Governments have been vocal about subsidizing prices, building political capital from this undertaking. Ensuring low prices has also been intertwined with a dominant discourse of energy security, entailing the government's and companies' ability to secure access to inexpensive energy resources. This has also warranted the state's objective to consolidate domestic ownership of energy assets that underpinned low prices and secure supplies. The Paks nuclear power plant's role at the heart of Hungary's energy system has made it a key constituent of domestic energy discourse, especially since MVM launched the planning and construction of its successor, Paks II. These four interlinked discourses have dominated the Hungarian energy scene essentially for decades, but have recently been expanded with climate change primarily in light of European and global developments.

Hungarian governments have a long-standing history in controlling energy prices, by developing domestic deposits or negotiating favorable import terms. Hungary has long produced and consumed fossil fuels, but this was especially accelerated when governments of the communist era accelerated industrialization (KBM 2008; VGF and HKL 2013). Demand for energy quickly outpaced supply and the country became reliant on inexpensive soviet hydrocarbon imports during the second half of the twentieth century (Hoffman and Dienes 1985). These factors laid the foundation to a discourse emanating from essentially all cabinets of the government and the party that focused on sustaining access to imports and low costs, which continued following the regime change. Energy prices remained a pervasive political issue that political parties heatedly debated, while Hungary's oil and natural gas major, MOL, provided energy to consumers at subdued prices, incurring the associated losses. Meanwhile, broader society expected the state to find a way to sustain low end-user prices. The need for the state to take action to secure access to inexpensive energy sources was especially pertinent given the technological and infrastructural lock-ins (e.g., an extensive natural gas network) that also drove a proliferating energy poverty throughout the country (Bouzarovski et al. 2016).

Political parties in Hungary have avoided raising energy prices by all means possible after being voted into office by the populace. The confluence of liberalization and high 
global energy prices led to climbing prices in the 2000s, culminating under the rule of the Hungarian Socialist Party (MSZP) (Ürge-Vorsatz et al. 2006). By this time, EU-backed liberalization efforts had been implemented by the government and E.ON had acquired a large part of the Hungarian energy sector, but these actors' discursive emphasis on a competitive market benefitting the consumers did not materialize. PM Orbán-led Fidesz launched a campaign for the need to maintain low energy prices and reclaim energy assets, contributing to their win at the polls in 2010, 2014, and 2018. In the run up to the 2014 election, "utility [price] reductions" [rezsicsökkentés] was the dominant discursive theme of the campaign and after winning office. Fidesz widely publicized its overhead price reductions and launched an era of the "fight for utility prices" [rezsiharc] (Böcskei 2015; Horváth 2016). The "fight for utility prices" included a bid to shape prices and to allow the state to nationalize energy assets, concentrating ownership in public companies (Mihályi 2018). Fidesz reversed MSZP-led governments' actions to open the Hungarian energy sector for foreign investors, which it already began in 2011 with a large stockpurchase share in the national oil company MOL and followed with further acts of sectoral consolidation after its 2014 re-election. The guiding rhetoric the government has deployed claims that energy assets are strategic and therefore should be Hungarianowned, while this form of ownership also ensures energy security.

The nationalization of energy assets in Hungary is embedded in the wider discourse of supply security, given the import dependence that the country has built in past decades (see section "Composition of the Energy Mix"). This is predicated on the country's need to exploit domestically available resources, maintain amicable relations with Russia, and diversify import routes. The Hungarian energy system is set up in a manner where actors throughout the supply chain rely on good relations with Russia, ensuring a secure supply of energy resources at subdued prices. Consequently, there is a strong Russia-friendly element of the government's foreign policy, which has become especially pronounced and discursively emphasized in recent years under Fidesz governments. This has been accompanied with government-backed initiatives to diversify energy import sources and routes, ushering in a strong focus on natural gas pipeline politics especially following the 2006 and 2009 natural gas crises (Weiner 2017). Decision-makers from the public and private sector extensively discussed large infrastructure projects including the Nord Stream, Nabucco pipeline, South Stream, the Trans-Adriatic Pipeline, the Azerbaijan-Georgia-Romania-Hungary LNG project (AGRI), Krk LNG, Turkish Stream, Nord Stream 2, the Bulgaria-Romania-HungaryAustria pipeline (BRUA), and interconnectors to neighboring countries (e.g., Slovakia and Croatia). Representatives of the EU and the USA have continuously articulated their support for undertakings delivering non-Russian natural gas. Many of these projects were heatedly debated for years, but few have come to fruition given the preexisting lock-ins of the energy system and Hungary's unwillingness to pay the surplus price for non-Russian hydrocarbons.

Hungary's focus has also been targeted to address supply security and price issues by leveraging domestic sources of energy, which includes the exploitation of lignite, oil, and natural gas, as well as continuing domestic nuclear power-based electricity generation. The need to sustain domestic fossil fuel production has been a key point of discourse emphasized by government officials and the upstream industry at large. 
However, lignite deposits are of weak quality and hydrocarbon reserves are rapidly being depleted by producers, leaving the future of these energy sources in question. Moreover, they may enhance supply security and energy autonomy, but their production is not economically competitive. Nuclear power, however, continues to be a staple of Hungary's energy and broader political discourse, given its intimate linkages to the country's foreign policy towards Russia. The government and state-owned firms (e.g., MVM) have continuously emphasized the need for Paks to be expanded, since the current reactors will have to be retired in the 2030s and are a key source of domestically produced energy. Surveys show that $61 \%$ of society is generally against the construction of an additional Russian-financed nuclear power station (Greenpeace Hungary 2018). Fidesz supporters have been slightly in favor of the project, which has also fused with their positive perception of Russia (Hargitai 2018; Magyari 2018). The populace favors renewables over nuclear, which are seen as tools to mitigating exposure to Russian influence, thereby enhancing energy security.

Climate change has only become a recent addition to prominent energy discourses in Hungary. There had been a wave of focus on renewable energy in the early-2000s that led to the expansion of wind generation capacities, but this came to an abrupt halt, when the government decided to suspend support for wind and essentially ban the technology. The founding of Hungary's green party, Politics Can Be Different (LMP), in 2009 provided some impetus for a more environmentally conscious dialogue in the Parliament and in wider society. Meanwhile, Hungarian media's reporting of the Energiewende and the potential of renewables remained subdued (Antal and Karhunmaa 2018). Integration into the European Union (Kerényi and Szabó 2006), the Paris Agreement, and the European Commission's (2016) introduction of the Clean Energy Package began to shift the prominence of environmental and climate discourse. However, this only rose in prominence in 2019, when the Fidesz-led government lost key cities in municipal elections, where climate and environmental action was an important factor that mobilized voters. Fidesz went from snubbing EU 2050 climate goals, to a proponent of climate action (Jávor 2020). Carbon lock-ins still dominate the climate discourse, since the government has continuously emphasized the need for prudent action in phasing out emitting sources of energy and underscoring that nuclear is a carbon-neutral technology - thus, Hungary should support Paks II on climate grounds as well - but as the costs of renewables decline their potential is increasingly incorporated into societal discourses and future planning.

\section{Coordination of the Instruments and Issues of Energy Transitions Within a Multilevel Context}

\section{Drivers of Energy Transition}

Energy security and pressure from Western institutions to enact change are the prime drivers of Hungary's energy transition. The former has been a continuous concern for the country with governments, the private sector, and society seeking to ensure the accessibility and affordability of imported energy, since domestic fossil fuel 
resources are insufficient to meet demand. In principle, an energy transition provides an opportunity for Hungary to reduce its import reliance and meet its energy needs through domestic production. This should entail a shift away from imported fossil fuels towards domestically sourced energy, primarily via renewables. Domestically produced renewable-based electricity offers an opportunity to reduce the importreliance of the country - approximately one third of demand (see section "Composition of the Energy Mix"). The forthcoming need to retire the Mátra Power Plant further pressures the government to take action and deploy renewables to avoid a hike in import reliance. The state has also accepted nuclear as a source of domestic energy that maintains supply security reliant on low-carbon technologies. These ambitions generally impede an energy transition (Antal 2019), but the government has been adamant as framing the project as an integral part of a transition to a low-carbon energy system, despite Paks' and Paks II's reliance on foreign technology and source-fuel. Energy security is thus a driver of Hungary's energy transition to renewables, but renewable penetration is impeded by nuclear which the government has also supported on inter alia energy security grounds.

A strong push of EU climate goals and obligations as well as the rising competitiveness of renewables have complemented energy security considerations driving Hungary's energy transition. The European Union has been a self-proclaimed leader in climate action, which has led the European Commission to set binding goals (e.g., renewable deployment targets) and introducing mechanisms (e.g., EU ETS) to decarbonize its economy (Maltby 2013). The European Commission (2008, 2011, 2014) pushed for an energy transition in its 2020, 2030, and 2050 goals, which Western European countries came to support (Sattich 2018). Hungary, like most European countries, took little action prior to the 2010s, apart from a wave of investment in wind power generation between 2000 and 2010, leading to the 325 MW of capacity still online (MAVIR 2019). Many Western European countries accelerated their energy transitions in the early-2010s, but initially this had little influence on Hungarian policy-makers. Fossil fuel and nuclear lock-ins sustained. Simultaneously, the government was able to claim that it was en route to meeting emission targets, since its targets were unambitious (see section "Strategies and Instruments of Energy Transition"). The composition of the energy mix saw little change, apart from an abrupt rise in the share of biomass (see section "Strategies and Instruments of Energy Transition") - a result of a shift in statistical accounting as opposed to substantial change (Hvg.hu 2017). Drivers of the energy transition remained insufficient to effectuate any substantial change in Hungary until the mid-2010s, but allowed the country to move towards its 2020 EU targets. The forthcoming decade through 2030 is what seems to pose a much greater challenge and induce wide-ranging change.

The acceleration of Western Europe's energy transition increasingly pressured Central and Eastern Europe's EU members to take action (Szabo and Deak 2020). Lock-ins of energy consumption patterns sustained and renewables could not yet challenge the price of fossil fuels. The government-supported lock-in of nuclear technology also formed an impediment to the diffusion of renewables, as policymakers' ambitions to construct Paks II overshadowed most other energy policy 
objectives in Hungary (Antal 2019). However, it has become clear that Hungary has to facilitate the diffusion of renewables, its technology of choice is solar PV, to meet 2020 and $2030 \mathrm{EU}$ targets. To facilitate the transition, the Commission has applied carrot and stick approach to push EU member states to meet obligations, by providing some funding for renewables and increasing energy efficiency. This has been a lure that has driven Hungary's energy transition. Simultaneously, the EU ETS penalizes the consumption of high emission fuels and has recently become a policy vehicle with teeth, as allowance prices rose to the EUR 20-25 band (see section "Composition of the Energy Mix"). In the short term, energy companies have had to rely on imports, but these factors can lead investment into renewables. The Commission's other stick is the measures it can take against member states who do not meet renewable energy targets they set for 2020 and 2030. If and how the Commission will take action in these cases is unclear for now.

The political imposition of renewable penetration by EU-level institutions is complemented by the rising competitiveness of renewables. Technological advancements and economies of scale have led wind turbines and solar photovoltaics to become competitive with their fossil fuel counterparts (Lazard 2018). Hungary also has a generally favorable setting that allows producers to harness wind and solar energy and relatively high utilization rates (Pálfy 2017). This, paired with the urgent need to invest in domestic electricity generation capacities given the forecasted gap in demand and supply, has led investors to show heightened interest in the Hungarian market (MAVIR 2018). The government has also provided ample support for the diffusion of renewables (see section "Strategies and Instruments of Energy Transition"). As the relative competitiveness of solar PV continues to rapidly increase, market forces are taking over political obligations in driving the energy transitions. Projects may still rely on some state support, but developers expect that the market will move away from this reliance and solar PV will gradually outcompete other modes of electricity generation, provided that a favorable environment (both legalregulatory and socio-technical) is maintained. Enmeshed in these drivers is a sliver of industrial policy that began to adapt the Hungarian economy for a decarbonized world, by backing lithium-ion battery, solar PV, and electric bus production. Overall, drivers for Hungary's energy transition are thus political and primarily externally imposed, with some impetus provided by energy security considerations.

\section{Strategies and Instruments of Energy Transition}

Hungary's energy transition strategy has relied on it being embedded in the EU's climate and energy governance structures. This sets some targets and the broad framework, within which the country can navigate and develop its strategies to meet its goals. The EU imposed a legally binding obligation on Hungary to include a $13 \%$ minimum share of renewables in gross final energy consumption by 2020, while the government set an even more ambitious target of $14.65 \%$ (European Parliament and Council 2009b; NFM 2010). Subsequently, Hungary adopted a 21\% target for 2030 (ITM 2020c). Due to a 2017 change in the EU's accounting methodology of 
biomass, it seemed that Hungary would swiftly meet its 2020 renewable targets, with renewables' relative share climbing to a peak of $16.2 \%$ in 2013 , heavily predicated on biomass (Fig. 1). However, despite this boost, the relative role of renewables has been going downhill since then. The temporary optimism has deferred focus on the diffusion of nonbiomass renewables and may have hindered an even quicker deployment of solar PV (HVG 2017). The government recently reversed this course of action, heavily promoting the diffusion of solar PV to enable the country in meeting 2020 EU targets (ITM 2020a, c).

The heating and cooling sector will continue to be responsible for highest share of the renewable consumption, where the share of renewables may increase from $18.1 \%$ in 2018 to $28.7 \%$ in 2030 (Table 1) (ITM 2020a, c; MEKH 2020h). The NECP aims to decrease gas consumption and the role of gas both in residential individual household- and in district heating by the combination of energy efficiency measures and fuel mix diversification. However, according to the NECP, Hungary will also reduce residential firewood use. The NECP supports further heat pump installations and efficient biomass-heating solutions. The role of gas is set to be substituted in district heating through the introduction of more renewables, such as biomass and geothermal energy. In addition, the NECP places emphasis on recovering energy from nonrecyclable waste and the use of biogas from sewage, landfills, and agricultural waste materials for district heating. The NECP states that the replacement of natural gas-based district heating with renewable-based heat production will not be carried out on a market basis; rather, it requires substantial investment support through instruments such as the Green District Heating Program (ITM 2020c). Therefore, in the 2014-2020 programming period, investment is provided for the construction of renewable-based heat generation, which may facilitate significant growth in biomass-based and geothermal energy.

The low-carbon electricity sector envisioned in the NECP will continue to be based mainly on nuclear energy, partly preserving the old model with baseload power and a centralized structure provided by a large and inflexible power plant, but complemented with renewables. The role of renewables in gross electricity consumption will increase from $8.3 \%$ in 2018 to $21.3 \%$ in 2030 and $29.3 \%$ in 2040 per the so-called WAM ("with additional measures") scenario, reflecting additional measures to be taken, as compared to the WEM ("with existing measures") scenario (Fig. 1) (ITM 2020a; MEKH 2020h). On the generation side in the WAM scenario, the share of renewables is projected to grow from $11.6 \%$ in 2018 to $19.7 \%$ in 2030 and $44.1 \%$ in 2040 . The combined share of renewables and nuclear in the electricity mix is planned to be $78.6 \%$ in 2030 and $90.7 \%$ in 2040 from $60.8 \%$ in 2018 (Fig. 2) (ITM 2020a; MEKH 2020a). The four Soviet-designed units (500 MW each) at the Paks power station in operation will be phased out in the 2030s, after the end of their 20-year lifetime extension program. Although uncertainties are large, the two new units are planned to be commissioned until 2030, with a slightly higher combined capacity (two units of $1200 \mathrm{MW}$ each) than that of the four old units. Therefore, the share of nuclear power will surge by 2030 and then decline. In 2030, Hungary plans to be almost self-sufficient in electricity on a yearly basis (ITM 2020c). 
The government's centralized and nuclear-centric approach to the energy transition in inter alia the NECP reflects its skepticism towards the reliability of intermittent renewables, weighing on their expansion. However, external, mainly EU, pressure and the rising competitiveness of solar PV have changed this situation. The government has chosen solar PV as the renewable of the future, providing it ample backwind. According to the NECP's WAM scenario, the technology's share in output will increase from $1.9 \%$ in 2018 to $3.9 \%$ in $2020,11.5 \%$ in 2030 , and $29.3 \%$ in 2040 (Fig. 2) (ITM 2020a; MEKH 2020a). The anticipated rapid spread of solar PV across Hungary will strengthen decentralized energy system structures. Biomass can also continue to expand and may provide an easy way to increase the role of renewables in electricity. On the other hand, the Hungarian government does not intend to exploit the remaining wind potential. It introduced a de facto ban on new wind power plant projects in 2016, with no new permits issued since 2006 . There are multiple theories as to why this executive decision was taken, a plausible one of which is that the technology was overly linked to the Socialist government's scandalous distribution of construction quotas in 2006 - an act that the Fidesz government had looked to distance itself from (Weiner 2019). We also see this ban linked to the government's energy policy priorities that focused on Paks II. Lastly, hydro potential is also not likely to be utilized (ITM 2020a).

The government has driven renewable electricity generation through various support schemes. The first of these was KÁP in place between 2003 and 2007, followed by the KÁT between 2008 and 2016. The third generation of support schemes (METÁR) was launched in 2017 (Haffner 2018). Not only does METÁR provide operating aid for electricity generation, but it also facilitates market integration of renewable energy production. According to the original plans, power plants with a capacity of less than $0.5 \mathrm{MW}$ or pilot technologies and projects were to be eligible for support (METÁR-KÁT), while METÁR's green premium was to be granted without a tender for installations with a capacity of between $0.5 \mathrm{MW}$ and $1 \mathrm{MW}$, and through a tender for facilities with a capacity of at least $1 \mathrm{MW}$. Ultimately, projects with a capacity of under $0.5 \mathrm{MW}$ were also included in the premium scheme, and the fixed-rate feed-in tariff option ceased to exist. In addition to supporting the building of new units, the METÁR system also supports the preservation of existing renewable energy capacities through METÁR's brown premium system. Hungary will distribute a maximum annual amount of HUF 45 billion (EUR 130 million) within the framework of METÁR through 2026 (ITM 2020c).

The maturity of solar PV technology and the safe investment it provided prompted developers to submit over $1 \mathrm{GW}$ of project proposals before the KÁT system was set to expire at the end of 2016 (Kulcsár 2019). Developers are still realizing projects from this wave of proposals, which have contributed to total solar PV capacities increasing to $1144 \mathrm{MW}$ in mid-2019 from $321 \mathrm{MW}$ at the end of 2017 (MEKH 2019a). Subsequently, the government waited until 2019 to launch a tender under the METÁR scheme, as its foot-dragging to introduce further change continues. Nonetheless, investors still see Hungary's geography as favorable for solar $\mathrm{PV}$, but issues such as grid connection and instability in the regulatory environment 
weigh on the diffusion of the technology as the government continues to hesitate to take action that would accelerate the energy transition. Hungary also encourages the installation of solar PV systems, partially replacing household electricity consumption drawn from the grid. There is an interest-free energy-efficiency loan in the Hungarian market that has been offered to households since 2017, but the Hungarian regulation on the energy characteristics of buildings is the one which is expected to drive further exponential growth of production units currently defined as small-scale household power plants, since it requires that at least $25 \%$ of the energy needs of new public and residential buildings should be covered by renewables post-2018 and post-2020, respectively. The 2030 target of the NECP is to have at least 200,000 households with roof-mounted solar panels averaging $4 \mathrm{~kW}$ each from 29,593 smallscale household solar PV power plants at end-2017 (ITM 2020c; MEKH 2019b).

Despite strategies to expand renewable-based power generation, nuclear, natural gas, and coal still dominate the country's domestic electricity scene. Lignite still enjoys a solid position in Hungary, but its NECP established 2030 as the year for achieving a lignite-free power sector (ITM 2020c). Since then, the respective minister has fast-tracked this objective to 2025 (Marczisovszky 2020). Internalizing instruments are strongly affecting the future of the lignite-fired Mátra Power Plant which buys $100 \%$ of its $\mathrm{CO}_{2}$ quotas (Mert.hu n.d.). The power plant's profitability thus depends primarily on electricity and carbon prices, and consequently under the current market conditions, it is a loss-making operation. The NECP expects the role of gas in electricity generation will increase until significant PV capacity enters the grid and Paks II starts operating (ITM 2020a). However, after that time, gas-based generation will decrease both in absolute and relative terms, but gas will continue to play an important role in electricity generation as a flexible peaking resource or a standby reserve in the electricity system.

Growth in renewable energy consumption in the transport sector has primarily been attributable to the use of biodiesel produced from first generation (food and feed crops-based) biofuels and used cooking oil. In 2020, the government increased the mandatory blending ratio to $8.2 \%$ of biofuels, driving a $6.1 \%$ blending percentage of bioethanol in gasoline (ITM 2020c). Despite some action, Hungary is unlikely to meet its relevant $2020 \mathrm{EU}$ target requiring a $10 \%$ share of renewables in the transport sector by 2020, which stood at 7.7\% in 2018 (Fig. 1) (MEKH 2020h; ITM 2020a). According to the NECP's WAM scenario, the share of energy from renewable sources used for transport could increase to $16.9 \%$ in 2030 and $28.8 \%$ in 2040 (Fig. 2) (ITM 2020a), compared to the minimum binding target of $14 \%$ in 2030 (European Parliament and Council 2018a). In order to achieve at least the latter goal, the government plans to raise the proportion of first-generation biofuels to nearly $7 \%$, while the share of second generation biofuels and biogas should be raised to $3.5 \%$. The remainder will hinge on transportation's electrification. Hungary supports the spread of electric vehicles with financial instruments, including direct subsidies for individuals seeking to purchase these vehicles and tax breaks. It is also implementing programs that encourage the spread of electromobility through the development of charging infrastructure. Moreover, the country is also expected to put nearly 1300 environmentally friendly buses into operation by 2029 through the 
Green Bus Program. In addition to public transport, natural gas and biogas can play a greater role in freight transport (ITM 2020c).

Hungary has taken on modest energy efficiency targets in comparison to the EU's overall goals, but even so, it may face difficulties in meeting its 2030 final energy consumption target. Primary and final energy consumption reached 1025 PJ and 776 PJ in 2018 (MEKH 2020f), respectively, with 2020 targets of 1009 PJ and 693 PJ (Government Decree 1160/2015 [III. 20.]). Residential final energy consumption was 244 PJ in 2018 (MEKH 2020f), despite the government's former goal set at 207 PJ for 2020 (NFM 2015, 18). Hungary is far from this goal. Meanwhile, the government aims to keep Hungary's final energy consumption below 2005 levels in 2030 (Government Decree 1772/2018 [XII. 21.]). This represents a modest commitment in light of the fact that the EU decided to reduce final energy consumption by $20 \%$ compared to the 2005 levels (European Parliament and Council 2018b). In its WEM scenario, the NECP assumes an $18.7 \%$ increase in the final energy consumption between 2015 and 2030. And even if the WAM scenario materializes, final energy consumption will still increase by $7.6 \%$ in this period. There is only a 9.4\% difference between the 2030 final energy consumption data based on WEM and WAM. In contrast, the NECP expects final household energy consumption to decrease by either $0.8 \%$ or $31.7 \%$ depending on existing or additional policy measures (ITM 2020a), indicating that Hungary's total final energy consumption target depends on the exploitation of the residential energy savings potential, which, however, would require further proactive intervention (Table 3).

Hungary has to take vastly larger efforts to increase energy efficiency and renewable penetration rates in comparison to meeting its GHG targets. The NECP suggests that with existing measures GHG emissions would rise to $62.8 \mathrm{MtCO}_{2} \mathrm{q}$ by 2030 , beyond the $40 \%$ reduction in emissions compared to 1990 level Hungary has committed to. With additional measures, Hungary will be able to reduce them to 56.2 $\mathrm{MtCO} 2_{2} q$ by 2030 , slightly below its target of $56.3 \mathrm{MtCO}_{2} q$. Since the Mátra Power Plant is responsible for around six million tons of annual $\mathrm{CO}_{2}$ emissions (Napi.hu. 2016), the majority of the target can be met by eliminating lignite use. While GHG emissions under the ETS must fall significantly, the situation is much better in sectors outside the ETS. As part of the EU's 2009 Effort Sharing Decision, Hungary can increase its emissions by $10 \%$ between 2013 and 2020, relative to 2005 emissions levels (European Parliament and Council 2009a). It is unlikely to do so. In contrast, as part of the 2018 Effort Sharing Regulation, emissions for sectors outside the ETS should be reduced in Hungary by 7\% between 2021 and 2030, in relation to its 2005 levels (European Parliament and Council 2018c), ushering a disruptive force into Hungary's energy system.

\section{Coordination Mechanisms and Multilevel Governance}

Hungary's energy governance features a horizontally fragmented and vertically integrated decision-making system that heavily relies on the goals and ambitions of PM Orbán, although shaped by the historical legacies of the country and its 


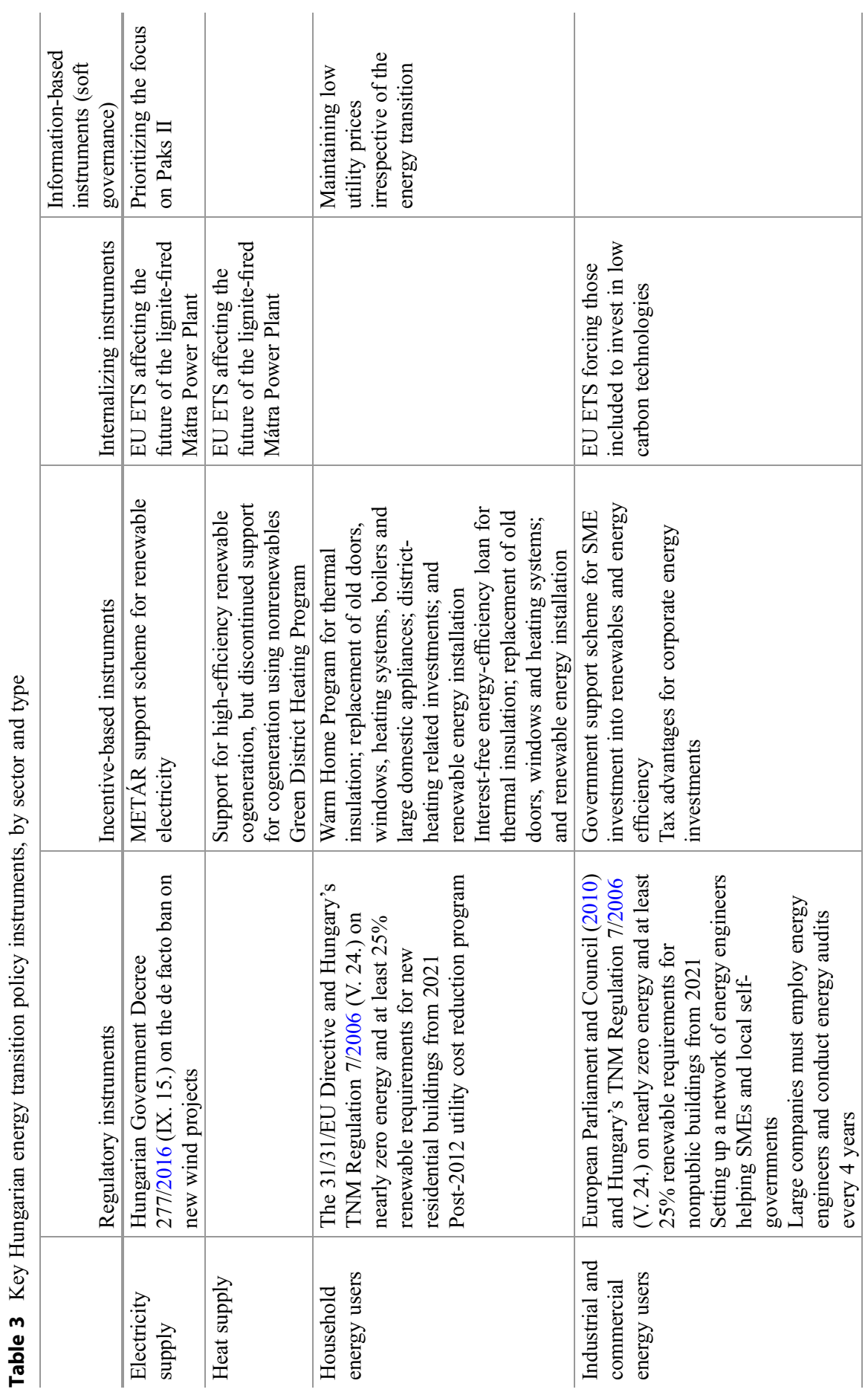



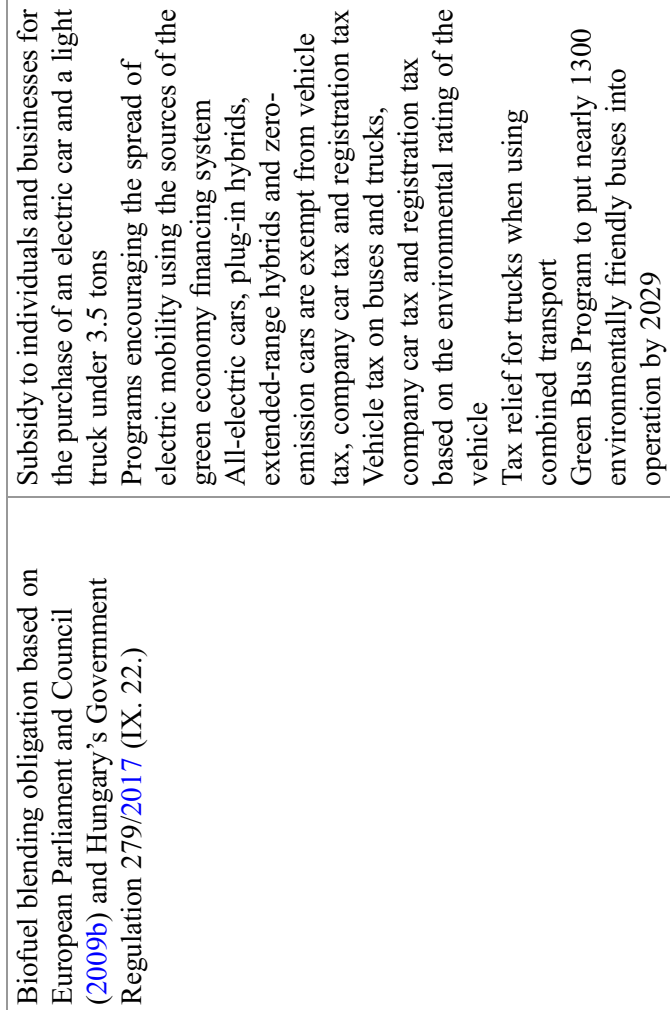

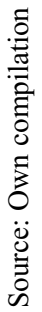


dialogue with the EU. Coordination mechanisms, including strategy design, are shaped by the dialogue between the Prime Minister's office, as well as decisionmakers in the EU and Russia. The Hungarian government has continuously engaged with EU policy-makers in an attempt to lower climate action-related targets. This has become especially evident in European Council meetings, where the country was continuously seen as a laggard and one that sought to obstruct the acceptance of targets, primarily since it sought to ensure that the EU provides it with ample funding to finance its transition. On the other hand, Hungary has maintained strong ties to Russia, which are heavily based on its energy system. The government's continued goal to ensure access to ample natural gas supplies at favorable prices and its bid to construct Paks II were coordinated at the highest levels of government with essentially no input from other actors.

Coordination in Hungary's energy scene primarily takes place between the highest levels of government, from where implementation is managed through a top-down approach. Various branches of the ministry possess competences over decision-making, but their positions are subjugated to the goals of the PM's office, as is the role of MEKH. The increasing state ownership of energy firms has also limited their ability to challenge government policy, instead, taking orders or shaping policy in close coordination with political decision-makers. Lastly, the Orbán regime has systematically sought to curtail the voices of NGOs, limiting their ability to become involved in energy governance as well. Meanwhile, a portion of the populace may be developing into prosumers over the past few years, but this has only had a minor impact on the overall landscape of energy governance.

\section{Outcomes, Challenges, and Prospects of Energy Governance}

This chapter has shown that the future of Hungary's energy governance relies on two basic factors: the Orbán regime's objectives and the broader energy trends impacting CEE countries. The objectives of PM Orbán's regime-building have clearly materialized. Fidesz governments have fortified the current setup since 2010, where governance-design reflects objectives of subduing prices, maintaining national ownership and pervasive institutional fragmentation, as well as hands-on control from the highest echelons of politics - all of which have become key descriptors of the country's illiberal energy governance regime. These objectives have been nested in the broader setting of a Russian energy dependent CEE country, where the lock-ins of existing consumption patterns are extremely powerful as is the disruption executed by the EU. Regional market, technology, and industrial developments, as well as international security considerations are set to continue to shape energy policies. Even if Hungarian political and policy designs are not fully congruent with those of its neighbors, we postulate that limitations posed by national self-rule will continue to be a basic policy benchmark. These two sets of factors provide an overarching framework, within which Hungary's energy system has shown some flexibility and adaptability, primarily in response to external pressure from the European Union. 
Hungary's low-carbon energy transition is particularly interesting and challenging, since the country will implement this in a unique, in some regards, archaic policy setup. Its policy objectives frequently contradict one another, but leave space for a high number of variegated configurations. Hungarian energy policy should keep household prices low in a time when price intensity of energy and its networks have been on the rise. It also needs to limit price hikes for industrial consumers to maintain economic competitiveness, while raising domestic investments from current untenably low levels. Energy policy shall simultaneously maintain the government's control over the sector, capture its rents, while forging new coalitions with emerging constituencies, companies, and institutions of the ongoing energy transition. It also has to transform the country's industrial policy, shifting its heavy reliance on combustion car manufacturing to meet the demands of e-mobility, while its capabilities as a high-value added host country have been fading away. In meeting these contradicting goals, key actors of Hungarian energy governance will have to carefully maneuver between its legacies that closely link it to Russia and the commitments the country has taken on by joining the EU, without surrendering the government's bid to enhance energy security.

Investment into electricity infrastructure (including power generation, transmission, and distribution) plummeted in recent years, which stands in sharp contrast with the need for investment into the sector to meet demand and increase selfsufficiency per the government's rhetoric. Where will the investments come from? Meanwhile, projects launched reflect the Orbán government's preference towards equity subsidization through budgetary means from taxpayers' money, as is the case with the Paks II nuclear deal and solar capacity expansion. The former is entirely financed from the central budget without being reflected in consumer prices during its construction. The government's solar power expansion goal has to be met amid tight-fisted subsidies reliant on government support and EU funds. Other segments, like gas power plants and transmission networks, almost exclusively belong to domestic private- and state-owned companies, opening up the way for extensive bargaining with the government. This unfolds as actors understand the prospects of the sector, including the urgent need to expand their capacities and alter their business models to an age with high capacity demand but low utilization rates.

The prospects of Hungary's energy transition rely on its ability and willingness to overcome historical lock-ins. The Paks II case is particularly relevant in this regard. Opponents criticize the project, characterizing it as an old-fashioned, expensive investment, providing incremental exposure to Russian influence, and opening up excessive corruption opportunities through state financing. Undeniably, the government decision to develop the project can be described as a classic case of sectoral lock-in, when not only the choice of fuel, but also the decision-making process and major characteristics of the deal reflect the previous agreement from the 1970s. Paks II can be a major barrier to energy transition, since it saps the government's attention and resources away from renewables, capping their expansion. Even though the two sources of energy could work alongside one-another: nuclear providing baseload electricity generation and renewables an intermittent source of electricity. Moreover, the government's narrative suggests that nuclear is a low-carbon technology, which 
will provide cheap energy - pending the operating company will not repay capital costs - and contributing to low utility prices. From this angle, maintaining the current nuclear capacity beyond 2040 is an indispensable step to successful energy transition. On the other hand, potential delays of the project, high capital expenditure, sustainment of path dependencies, and its inhibition of renewable diffusion despite their plummeting costs all hinder Hungary's move to renewables. Nonetheless, Paks II continues to be at the heart of the government's energy policy agenda, shaping the prospects of the energy sector, while overriding essentially all other considerations.

After having extensively relied on biomass, solar PV has become the Hungarian government's main tool to meet EU-imposed climate targets and enhance energy security. In doing so, however, it has disrupted the energy system, corroding lockins, and shaping future energy prospects. The competitiveness of the technology would allow for a thriving market, but its full potential remains to be realized. State plans and strategies show growing support for solar PV, but simultaneously representatives urge caution and a moderate pace, to avoid the rapid disruption of energy producer-consumer relations. The scaling-up of solar PV would primarily impact electricity imports and substitute the lignite-based Mátra Power Plant's generation the latter of which has to be retired in forthcoming years. This substitution would only have a moderate impact on the country's energy security, leaving the hydrocarbon and nuclear-based Russia-centric geopolitical relations of Hungary in-tact for the foreseeable future. It is set to continue to rely on imported natural gas and oil for heating and industrial consumption as well as transportation, respectively. Biofuels and electric vehicles have been playing an increasing but still moderate role in the transportation sector, leaving their diffusion to be a task of the future. Meanwhile, district heating based on the rising consumption of biomass and the utilization of the country's geothermal potential remains untapped. As the government proposes its EU-mandated climate and energy plans, observers can attain a rough understanding of the country's planned trajectory. Specifics may be lacking, but it seems clear that the transition will be moderately paced and centrally controlled.

Hungarian energy governance conveys a unique disposition, filled with contradictions and lacking clarity. Much like many of its CEE neighbors, it is still entrenched in preexisting producer-consumer relations that shape its amicable relations with Russia. This, like most of the country's energy policy, is shaped at the highest political level. Multilevel governance is subordinated to anticipate or execute the objectives dictated by policy-makers in the highest echelons of government. Other actors have very limited powers to question, contradict, or substantially shape the government objectives. Power and control over public and private entities is concentrated in the hands of a few, who have continuously undertaken a balancing act between the forces and requirements posed by the EU upon Hungary and the relations that tie it to Russia. Solar PV has had some, but still limited impact on the country's energy scene. It decarbonizes the energy system, but carries limited ramifications in shaping the governance structures of the country, while continuing to exist in the shadow of nuclear power. In the nonelectricity sectors, natural gas continues to be dominant, entrenched by infrastructural path dependencies and 
through its role as the backbone of Hungary-Russia relations. Oil takes on a similar role as well. The real challenges in the Hungarian energy sector are set to increase as we move closer to 2030 and 2050 EU decarbonization and renewable energy targets, but it remains unclear how Hungary will enact the radical change necessary to meet these goals.

\title{
Cross-References
}

\author{
Energy Governance in Austria \\ - Energy Governance in Croatia \\ - Energy Governance in Russia: From a Fossil to a Green Giant? \\ - European Union Energy Policy: A Discourse Perspective \\ - EU-Russia Energy Relations \\ - Transition of Energy Systems: Patterns of Stability and Change
}

Acknowledgments Csaba Weiner's research was supported by the János Bolyai Research Scholarship of the Hungarian Academy of Sciences. We would like to thank the editors, Jörg Kemmerzell and Michèle Knodt, for their work on the volume, as well as Áron Buzogány for his helpful comments on this chapter.

\section{References}

Antal, M. (2019). How the regime hampered a transition to renewable electricity in Hungary. Environmental Innovation and Societal Transitions, 33, 162-182. https://doi.org/10.1016/j. eist.2019.04.004.

Antal, M., \& Karhunmaa, K. (2018). The German energy transition in the British, Finnish and Hungarian news media. Nature Energy, 3(11), 994-1001. https://doi.org/10.1038/s41560-0180248-3.

Báger, G., \& Kovács, Á. (2004). Privatizáció Magyarországon I. kötet [Privatisation in Hungary, Vol. I]. Budapest: Állami Számvevőszék. https://www.asz.hu/storage/files/files/Publikaciok/ Archiv tanulmanyok/privatizacio.pdf?download=true. Accessed 5 Mar 2020.

Benczes, I. (2016). From goulash communism to goulash populism: The unwanted legacy of Hungarian reform socialism. Post-Communist Economies, 28(2), 146-166. https://doi.org/ 10.1080/14631377.2015.1124557.

Böcskei, B. (2015). Rezsicsökkentés: a közpolitikai változás mint politikai innováció [Utility price reduction: Public policy change as political innovation]. Politikatudományi Szemle, 24(4), 94 114. https://www.ceeol.com/search/article-detail?id=366236. Accessed 10 Feb 2020.

Bouzarovski, S., Herrero, S. T., Petrova, S., \& Ürge-Vorsatz, D. (2016). Unpacking the spaces and politics of energy poverty: Path-dependencies, deprivation and fuel switching in postcommunist Hungary. Local Environment, 21(9), 1151-1170. https://doi.org/10.1080/ 13549839.2015.1075480.

BP. (2019a). Statistical review of world energy - All data, 1965-2017. BP - Definitions and explanatory notes. https://www.bp.com/en/global/corporate/energy-economics/statisticalreview-of-world-energy.html. Accessed 2 Apr 2019.

BP. (2019b). BP statistical review of world energy 2019. https://www.bp.com/content/dam/bp/ business-sites/en/global/corporate/xlsx/energy-economics/statistical-review/bp-stats-review2019-all-data.xlsx. Accessed 4 Oct 2019. 
EASAC (European Academies' Science Advisory Council). (2019). Leading scientists warn: Wood pellets threat to climate: "No silver pellet". European. https://www.ria.ie/news/policy-andinternational-relations-international-activities/leading-scientists-warn-wood. Accessed $14 \mathrm{Feb}$ 2020.

European Commission. (2008). Communication from the Commission to the European Parliament, the Council, the European Economic and Social Committee and the Committee of the Regions: 2020 by 2020 - Europe's climate change opportunity. $\operatorname{COM(2008)} 30$ final. https://eur-lex. europa.eu/legal-content/EN/TXT/?uri=CELEX:52008DC0030. Accessed 7 Aug 2019.

European Commission. (2011). Communication from the Commission to the European Parliament, the Council, the European Economic and Social Committee and the Committee of the Regions: A Roadmap for moving to a competitive low carbon economy in 2050. COM(2011) 112 final. http://eur-lex.europa.eu/legal-content/EN/TXT/?uri=CELEX:52011DC0112. Accessed 21 Nov 2017.

European Commission. (2014). Communication from the Commission to the European Parliament, the Council, the European Economic and Social Committee and the Committee of the Regions: A policy framework for climate and energy in the period from 2020 to 2030. COM(2014) 15 final. https://eur-lex.europa.eu/legal-content/EN/TXT/?uri=CELEX:52014DC0015. Accessed 11 Feb 2020.

European Commission. (2016). Communication from the Commission to the European Parliament, the Council, the European Economic and Social Committee, the Committee of the Regions and the European Investment Bank: Clean energy for all Europeans. COM(2016) 860 final. https:// eur-lex.europa.eu/resource.html?uri=cellar:fa6ea15b-b7b0-11e6-9e3c-01aa75ed71a1.0001.02/ DOC_1\&format=PDF. Accessed 17 Aug 2018.

European Parliament and Council. (2009a). Decision No 406/2009/EC of the European Parliament and of the Council of 23 April 2009 on the effort of Member States to reduce their greenhouse gas emissions to meet the Community's greenhouse gas emission reduction commitments up to 2020 . https://eur-lex.europa.eu/legal-content/EN/TXT/?uri=CELEX\%3A32009D0406. Accessed 9 Dec 2019.

European Parliament and Council. (2009b). Consolidated text: Directive 2009/28/EC of the European Parliament and of the Council of 23 April 2009 on the promotion of the use of energy from renewable sources and amending and subsequently repealing Directives 2001/77/EC and 2003/ 30/EC (Text with EEA relevance). https://eur-lex.europa.eu/legal-content/EN/TXT/? uri1/4CELEX:02009L0028-20151005. Accessed 29 Mar 2020.

European Parliament and Council. (2010). Consolidated text: Directive 2010/31/EU of the European Parliament and of the Council of 19 May 2010 on the energy performance of buildings (recast). https://eur-lex.europa.eu/legal-content/EN/TXT/?uri=CELEX:02010L003120181224. Accessed 29 Mar 2020.

European Parliament and Council. (2018a). Directive (EU) 2018/2001 of the European Parliament and of the Council of 11 December 2018 on the promotion of the use of energy from renewable sources (Text with EEA relevance). https://eur-lex.europa.eu/legal-content/EN/TXT/? uri=CELEX:32018L2001. Accessed 9 Dec 2019.

European Parliament and Council. (2018b). Directive (EU) 2018/2002 of the European Parliament and of the Council of 11 December 2018 amending Directive 2012/27/EU on energy efficiency (Text with EEA relevance). https://eur-lex.europa.eu/legal-content/EN/TXT/PDF/? uri=CELEX:32018L2002\&from=EN. Accessed 9 Dec 2019.

European Parliament and Council. (2018c). Regulation (EU) 2018/842 of the European Parliament and of the Council of 30 May 2018 on binding annual greenhouse gas emission reductions by Member States from 2021 to 2030 contributing to climate action to meet commitments under the Paris Agreement and amending Regulation (EU) No 525/2013 (Text with EEA relevance). https://eur-lex.europa.eu/legal-content/EN/TXT/?uri=celex:32018R0842. Accessed 9 Dec 2019.

Eurostat. (2018a). Supply, transformation and consumption of electricity: Annual data [nrg_105a]. (Last update: 04-06-2018). http://appsso.eurostat.ec.europa.eu/nui/show.do?dataset=nrg 105a\&lang=en. Accessed 30 Oct 2018. (This link does not exist anymore.) 
Eurostat. (2018b). Supply, transformation and consumption of heat: Annual data [nrg_106a]. (Last update: 04-06-2018). http://appsso.eurostat.ec.europa.eu/nui/show.do?dataset=nrg_106a\& lang=en. Accessed 30 Oct 2018. (This link does not exist anymore.)

Eurostat. (2020a). Complete energy balances [nrg_bal_c]. (Last update: 13-01-2020). https:// appsso.eurostat.ec.europa.eu/nui/show.do?dataset=nrg bal_c\&lang=en. Accessed 5 Feb 2020.

Eurostat. (2020b). Gross capital formation by industry [NACE A*64]. (Last update: 31-01-2020). https://ec.europa.eu/eurostat/data/database. Accessed 5 Feb 2020.

Eurostat. (2020c). Supply, transformation and consumption of electricity [nrg_cb_e]. (Last update: 31-01-2020). https://appsso.eurostat.ec.europa.eu/nui/show.do?dataset=nrg_cb_e\&lang=en. Accessed 5 Feb 2020.

Filippov, G. (2018, 31 July). A hibrid ellenforradalom kora [The age of the hybrid counterrevolution]. 24.hu. https://24.hu/belfold/2018/07/31/filippov-gabor-a-hibrid-ellenforradalom-kora/. Accessed 28 Feb 2020.

Government Decree 1160/2015 (III. 20.). http://www.kozlonyok.hu/nkonline/MKPDF/hiteles/ MK15036.pdf. Accessed 20 Dec 2019.

Government Decree 277/2016 (IX. 15.). https://net.jogtar.hu/jogszabaly?docid=A1600277.KOR\& timeshift $=20160923 \&$ txtreferer $=00000001$.txt. Accessed 31 Mar 2019.

Government Decree 1772/2018 (XII. 21.). https://magyarkozlony.hu/dokumentumok/ dd82ad295f630940ab7308cb468a715d71acb540/letoltes. Accessed 20 Dec 2019.

Government Regulation 279/2017 (IX. 22.). https://net.jogtar.hu/jogszabaly?docid=A1700279.KOR. Accessed 31 Mar 2019.

Greenpeace Hungary. (2018, 19 January). A magyarok túlnyomó többsége ellenzi Paks II-t, föként a projekt veszélyessége miatt [The majority of Hungarians oppose Paks II, mainly because of the project's dangers]. https://www.greenpeace.org/hungary/sajtokozlemeny/2317/a-magyaroktulnyomo-tobbsege-ellenzi-paks-ii-t-fokent-a-projekt-veszelyessege-miatt/. Accessed 10 Feb 2020.

Haffner, T. (2018). A megújuló energia termelés támogatásának intézményi változásai - a Megújuló Energia Támogatási Rendszer bevezetése [Institutional changes in support of renewable energy production: Introduction of renewable energy support scheme]. Közép-Európai Közlemények, 11(2), 17-29. http://vikek.eu/wp-content/uploads/2018/05/KEKNo412018.2.sz\%C3\%A1m. pdf\#page $=17$. Accessed 19 Nov 2018.

Hargitai, M. (2018, 23 July). Hatástalan a propaganda: nem akarjuk Paks 2-t [Ineffective propaganda: We do not want Paks 2]. Népszava. https://nepszava.hu/3002452_hatastalan-a-propa ganda-nem-akarjuk-paks-2-t. Accessed 15 Feb 2020.

Hoffman, G. W., \& Dienes, L. (1985). The European energy challenge: East and west. Durham: Duke University Press. https://trove.nla.gov.au/version/21773416. Accessed 27 Jun 2019.

Horváth, M. T. (2016). A fáraó varázsol. A rezsicsökkentés beágyazottsága [The magic of the pharaoh: The embeddedness of the utility price reductions]. Politikatudományi Szemle, 25(3), 135-146. http://real-j.mtak.hu/6520/26/Nyomdai\%20Poltud_Szemle_2016-03\%20bel\%C3\% ADv.pdf. Accessed 10 Feb 2020.

Hvg.hu. (2017, 3 April). Energia: zöldebbek lettünk, de ez nem sok jót jelent [Energy: We have become greener, but this does not mean much good]. https://hvg.hu/gazdasag/20170403 Energia_zoldebbek_lettunk_de_ez_nem_sok_jot_jelent. Accessed 11 Feb 2020.

ITM. (2019). Az innovációért és technológiáért felelős miniszter 4/2019. (II. 28.) ITM utasítása az Innovációs és Technológiai Minisztérium Szervezeti és Müködési Szabályzatáról [The Ministry of Innovation and Technology's decree on its organisational and operational rules]. https://www. kormany.hu/download/8/02/91000/Innov\%C3\%A1ci\%C3\%B3s\%20\%C3\%A9s\%20Technol\% C3\%B3giai\%20Miniszt\%C3\%A9rium\%20Szervezeti\%20\%C3\%A9s\%20M\%C5\%B1k\%C3\% B6d\%C3\%A9si\%20Szab\%C3\%A1lyzata.pdf. Accessed 2 Mar 2020.

ITM. (2020a). Magyarország Nemzeti Energia-és Klímaterve - 2-3. melléklet [Hungary's National Energy and Climate Plan - Annexes 2-3]. Budapest: ITM. https://www.kormany.hu/hu/dok? source $=11 \&$ type $=402 \# !$ !DocumentBrowse. Accessed 2 Feb 2020.

ITM. (2020b). Magyarország Nemzeti Energia- és Klímaterve - 4. melléklet [Hungary’s National Energy and climate plan - Annex 4]. Budapest: ITM. https://www.kormany.hu/hu/dok? source $=11 \&$ type $=402 \#$ ! DocumentBrowse. Accessed 2 Feb 2020. 
ITM. (2020c). Magyarország Nemzeti Energia- és Klimaterve [Hungary's National Energy and Climate Plan]. Budapest: ITM. https://www.kormany.hu/hu/dok?source=11\&type=402\#! DocumentBrowse. Accessed 2 Feb 2020.

ITM (Ministry for Innovation and Technology). (2018). National Energy and climate plan of Hungary (draft). Budapest: Ministry for Innovation and Technology (ITM). https://ec.europa.eu/energy/sites/ ener/files/documents/ec_courtesy translation_hu_necp.pdf. Accessed 25 May 2019.

Jávor, B. (2020, 15 January). Jávor Benedek: Új magyar klímapolitika - A fordulat éve? [Jávor Benedek: New Hungarian climate politics, the year of the turn?]. Mérce. https://merce.hu/2020/ 01/15/javor-benedek-uj-magyar-klimapolitika-a-fordulat-eve/. Accessed 10 Feb 2020.

KBM. (2008). A magyar bányászati termelés története [The history of Hungary’s mining]. Központi Bányászati Múzeum (KBM). http://www.kbm.hu/hu/node/6. Accessed 10 Feb 2020.

Kerényi, S., \& Szabó, M. (2006). Transnational influences on patterns of mobilisation within environmental movements in Hungary. Environmental Politics, 15(5), 803-820. https://doi. org/10.1080/09644010600937249.

KKM. (2019). A külgazdasági és külügyminiszter 4/2019 (III. 13.) KKM utasítása a Külgazdasági és Külügyminisztérium Szervezeti és Működési Szabályzatáról [The Ministry of Foreign Affairs and Trade's directive on its organisational and operational rules]. https://www.kormany.hu/ download/d/64/91000/A\%20K\%C3\%BClgazdas\%C3\%A1gi\%20\%C3\%A9s\%20K\%C3\%BCl \%C3\%BCgyminiszt\%C3\%A9rium\%20SZMSZ-e.pdf. Accessed 2 Mar 2020.

Kulcsár, B. (2019). Kötelezö átvételi rendszerben benyújtott naperőmü létesítési igények, megválósúlásának hatása a magyarországi településá llomány villamosenergia ellátására [The impact of realisation of solar power plant installation requests in Mandatory Purchase (KÁT) system on the electricity supply of Hungarian settlements]. International Journal of Engineering and Management Sciences (IJEMS), 4(2), 54-60. https://doi.org/10.21791/IJEMS.2019.2.6.

KWK-Index. (n.d.). Quarterly prices according to CHP law. European Energy Exchange. https:// www.eex.com/en/market-data/power/power-indices/kwk-index. Accessed 16 Jan 2020.

Lazard. (2018). Levelized cost of energy and levelized cost of storage 2018. Insights, 8 November. $\mathrm{https}$ :/www.lazard.com/perspective/levelized-cost-of-energy-and-levelized-cost-of-storage2018/. Accessed 13 Sept 2019.

Magyar, B. (Ed.) (2016). Post-communist mafia state: The case of Hungary. Budapest: CEU Press.

Magyari, P. (2018, 14 March). A fideszesek nagyon megszerették Putyint és Oroszországot [Fidesz supporters have really come to love Putin and Russia]. 444. https://444.hu/2018/03/14/afideszesek-nagyon-megszerettek-putyint-es-oroszorszagot. Accessed 15 Feb 2020.

Maltby, T. (2013). European Union energy policy integration: A case of European Commission policy entrepreneurship and increasing supranationalism. Energy Policy, 55, 435-444. https:// doi.org/10.1016/j.enpol.2012.12.031.

Marczisovszky, M. (2020, 19 February). Palkovics: 2025-től földgáz alapú lesz a Mátrai Erőmü [Palkovics: The Mátra Power Plant will be natural gas-based beginning in 2025]. Index.hu. https://index.hu/gazdasag/2020/02/19/matrai_eromu_palkovics_bejelentette_foldgaz_alapu/. Accessed 19 Feb 2020.

MAVIR. (2018). A magyar villamosenergia-rendszer közép- és hosszú távú forrásoldali kapacitásfejlesztése [The Hungarian electricity system's mid-and long-term supply side capacity expansions]. Budapest: MAVIR. https://www.mavir.hu/documents/10258/15461/Forr\%C3\% A1selemz\%C3\%A9s_2018_IG.pdf/fc043982-a8ea-e49f-6061-418b254a6391. Accessed $11 \mathrm{Feb} 2020$.

MAVIR. (2019). Data of the Hungarian electricity system, 2018. Budapest: MAVIR. http://mavir. hu/documents/10258/45985073/MAVIR_VER_2018.pdf/292fd722-ec62-2826-6e8d$1 \mathrm{bcd6c86c49c.} \mathrm{Accessed} 11$ Feb 2020.

MEHI. (2019, 7 February). 2017-ben immár harmadik éve nőtt az EU energiafogyasztása [EU energy consumption increases in 2017 for the third year]. https://mehi.hu/hir/2017-benimmar-harmadik-eve-nott-az-eu-energiafogyasztasa. Accessed 7 July 2019.

MEKH (Hungarian Energy and Public Utility Regulatory Authority). (2019a, 3 October). 1,1 GW összteljesítményt értek el a napelemek 2019 közepére [Solar PVs have reached 1.1 GW total generation by mid-2019]. http://www.mekh.hu/1-1-gw-osszteljesitmenyt-ertek-el-a-napelemek2019-kozepere. Accessed 11 Feb 2020. 
MEKH. (2019b). Összefoglaló a nem engedélyköteles - ezen belül a háztartási méretű kiserőmüvek adatairól (2008-2017) [A summary about small power plants that do not have to be permitted - including household sized installations]. http://www.mekh.hu/download/3/28/ 60000/nem_engedelykoteles_es_hmke_beszamolo_2008_2017.xlsx. Accessed 10 Jan 2020.

MEKH. (2020a). Annual data on gross electricity production, 2014-2018. (Date of the last update: in January 31,2020$)$. http://www.mekh.hu/download/4/c2/c0000/4_2_gross_electricity_produc tion_2014_2018.xlsx. Accessed 22 Feb 2020.

MEKH. (2020b). Annual data on heat production, 2014-2018. (Date of the last update: in January 31, 2020). http://www.mekh.hu/download/5/c2/c0000/5_1_thermal energy production_2014 2018.xlsx. Accessed 22 Feb 2020.

MEKH. (2020c). Annual natural gas balance 2014-2018. (Date of the last update: in January 31, 2020). http://www.mekh.hu/download/3/c2/c0000/3_2_annual_natural_gas_balance_ 2014_2018.xlsx. Accessed 22 Feb 2020.

MEKH. (2020d). Annual supply of crude oil, other primary oil and secondary petroleum products 2014-2018. (Date of the last update: in January 31, 2020). http://www.mekh.hu/download/1/80/ c0000/2_2_annual_supply_of_petroleum_and_petroleum_products_annual_2018.xlsx. Accessed $22 \mathrm{Feb} 2020$.

MEKH. (2020e). Final energy consumption of households, 2015-2018. (Date of the last update: in January 31, 2020). http://www.mekh.hu/download/9/c2/c0000/8_1_annual_energy_consump tion_of_households.xlsx. Accessed 22 Feb 2020.

MEKH. (2020f). National detailed energy balance - Eurostat format - (annual) 2014-2018. (Date of the last update: in January 31, 2020). http://www.mekh.hu/download/e/b2/c0000/7_4 orszagos_eves_\%20Eurostat_\%20tipusu_\%20reszletes_\%20energiamerleg_2014_2018.x1sx. Accessed 22 Feb 2020.

MEKH. (2020g). Production and consumption of primary renewable energy sources, 2014-2018. (Date of the last update: in January 31, 2020). http://www.mekh.hu/download/7/c2/c0000/6_2_ primary_renewable_en_sources_2014_2018.xlsx. Accessed 22 Feb 2020.

MEKH. (2020h). Share of renewable sources in gross final energy consumption, 2005-2018. (Date of the last update: in January 31, 2020). http://www.mekh.hu/download/6/c2/c0000/6_1_share_ of renewable_en_sources_2005_2018.xlsx. Accessed 22 Feb 2020.

Mert.hu. (n.d.). Mátrai Erőmü. Köszöntő [Mátra Power Plant: Greetings]. http://www.mert.hu/hu/ elnoki-koszonto. Accessed 9 Nov 2018.

Mihályi, P. (2018). A privatizált vagyon visszaállamositása [The re-nationalisation of privatized wealth]. Manuscript. Budapest: MTA KRTK. https://www.mtakti.hu/wp-content/uploads/2018/ 04/10_Visszaallamositas_KTRK_eloadashoz.pdf. Accessed 15 Feb 2020.

Mocsáry, J. (2001). Visszapillantás a privatizációra [Taking a look back on privatisation]. Eszmélet, 49. http://www.eszmelet.hu/mocsary_jozsef-visszapillantas-a-privatizaciora/. Accessed 27 Mar 2020.

Müller, J-W. (2014). Putinism, Orbanism . . But is there an "ism”? IWM. https://www.iwm.at/ transit-online/putinism-orbanism-ism/. Accessed 28 Feb 2020.

Napi.hu. (2016, 7 July). Az EU legszennyezőbb szénerőművei között a Mátrai Erőmű [Mátra Power Plant is one of the most polluting coal power plants in the EU]. https://www.napi.hu/magyar_vallalatok/az eu_legszennyezobb_szeneromuvei_kozott_a_matrai_eromu.617386.html. Accessed 4 May 2017.

NFM. (2015). Hungary's National Energy Efficiency Action Plan until 2020. Budapest: NFM. https://ec. europa.eu/energy/sites/ener/files/documents/hungaryActionPlan2014_en.pdf. Accessed 1 June 2019.

NFM (Ministry of National Development). (2010). National renewable energy action plan 2010 2020. Budapest: NFM. http://2010-2014.kormany.hu/download/6/b9/30000/RENEWABLE\% 20ENERGY_REPUBLIC\%20OF\%20HUNGARY\%20NATIONAL\%20RENEWABLE\% 20ENERGY\%20ACTION\%20PLAN\%202010_2020.pdf. Accessed 1 June 2019.

Orbán, V. (2014). A munkaalapú állam korszaka következik [The age of a work-based system is next]. Tusnádfürdő: Speech at the XXV. Bálványosi Summer University and Student Camp. https://www.kormany.hu/hu/a-miniszterelnok/beszedek-publikaciok-interjuk/a-munkaalapuallam-korszaka-kovetkezik. Accessed 28 Feb 2020.

Pálfy, M. (2017). A napenergia fotovillamos hasznosítása [Solar power's PV utilisation]. Magyar Tudomány, 178(5), 532-539. http://epa.oszk.hu/00600/00691/00164/pdf/EPA00691_mtud_ 2017_05_532-539.pdf. Accessed 11 Feb 2020. 
Pap, I. S. (2017, 3 November). A Kádár-rendszerről álmodoznak a magyarok [Hungarians reminisce of the Kádár system]. Mérce. https://merce.hu/2017/11/03/a-kadar-rendszerrolalmodoznak-a-magyarok/. Accessed 2 Mar 2020.

Sandbag. (n.d.). EUA price. https://sandbag.org.uk/carbon-price-viewer/. Accessed 7 Jan 2020.

Sattich, T. (2018). The international reverberations of Germany's Energiewende: Geoeconomics in the EU's geo-energy space. In D. Scholten (Ed.), The geopolitics of renewables (pp. 163-185). New York: Springer.

Scheiring, G. (2018). Lessons from the political economy of authoritarian capitalism in Hungary. Challenging Authoritarianism Series, no. 1. Amsterdam: Transnational Institute. https://www. tni.org/files/publication-downloads/tni-authoritarian-capitalism-in-hungary.pdf. Accessed 28 Feb 2020.

Stern, J. (2017). The future of gas in decarbonising European energy markets: The need for a new approach. OIES paper, NG 116. Oxford: Oxford Institute for Energy Studies. https://www. oxfordenergy.org/wpcms/wp-content/uploads/2017/01/The-Future-of-Gas-inDecarbonising-European-Energy-Markets-the-need-for-a-new-approach-NG-116.pdf. Accessed 15 May 2018.

Szabo, J., \& Deak, A. (2020). The CEE energy transition: Recurring 50 year old dynamics? In M. Matúš \& V. Oravcová (Eds.), From economic to energy transition - Three decades of transitions in Central and Eastern Europe. London: Palgrave Macmillan.

Szabo, J., \& Fabok, M. (2020). Infrastructures and state-building: Comparing the energy politics of the European Commission with the governments of Hungary and Poland. Energy Policy, 138, 111253. https://doi.org/10.1016/j.enpol.2020.111253.

Szvák, G. (Ed.) (2016). A magyarok orosz-képe (2006-2016) [Hungarians' image of Russians (2006-2016)]. Budapest: Russica Pannonica. https://www.russianstudies.hu/docs/Poszt.szovjet. f\%C3\%BCzetek.22..pdf Accessed 2 Mar 2020.

TNM Regulation 7/2006 (V. 24.). https://net.jogtar.hu/jogszabaly?docid=a0600007.tnm. Accessed 20 Dec 2019.

Ürge-Vorsatz, D., Miladinova, G., \& Paizs, L. (2006). Energy in transition: From the iron curtain to the European Union. Energy Policy, 34(15), 2279-2297. https://doi.org/10.1016/j. enpol.2005.03.007.

VGF \& HKL. (2013). A magyar olaj és földgáz története VI [The history of Hungary's oil and natural gas]. Viz, Gáz, Fütéstechnika és Hütö, Klíma, Légtechnika szaklap, 14(9). https://www.vgfszaklap. hu/lapszamok/2013/szeptember/3000-a-magyar-olaj-es-foldgaz-tortenete-vi. Accessed $10 \mathrm{Feb} 2020$.

Weiner, C. (2017). Managing energy supply security and gas diversification in Hungary: Putting theory into practice. IWE working papers, no. 238. Budapest: Institute of World Economics, MTA KRTK. http://real.mtak.hu/73435/1/WP_238_Weiner.pdf. Accessed 10 Feb 2020.

Weiner, C. (2019). Revisiting the management of stationary fuel supply security and gas diversification in Hungary. IWE working papers, no. 254. Budapest: Institute of World Economics, MTA KRTK. http://real.mtak.hu/94539/1/WP254_Weiner_Fuel_supply_security.pdf. Accessed 1 Oct 2019.

Wilkin, P. (2016). Hungary's crisis of democracy: The road to serfdom. Lanham/Maryland: Lexington Books. 